\section{BRS 331 - Early cycle double-haploid wheat cultivar}

\author{
Pedro Luiz Scheeren ${ }^{1}$, Eduardo Caierão ${ }^{1 *}$, Márcio Só e Silva ${ }^{1}$, \\ Luiz Eichelberger ${ }^{1}$, Alfredo do Nascimento Júnior ${ }^{1}$, Eliana Maria \\ Guarienti ${ }^{1}$, Martha Zavariz de Miranda ${ }^{1}$, Ricardo Lima de Cas- \\ tro $^{1}$, Leila Costamilan ${ }^{1}$, Flávio Martins Santana ${ }^{1}$, João Leodato \\ Nunes Maciel ${ }^{1}$, Maria Imaculada Pontes Moreira Lima ${ }^{1}$, João \\ Leonardo Fernandes Pires ${ }^{1}$, Douglas Lau ${ }^{1}$, Paulo Roberto Valle \\ da Silva Pereira ${ }^{1}$ and Gilberto Rocca da Cunha ${ }^{1}$
}

\begin{abstract}
The wheat cultivar 'BRS 331' was developed by Embrapa. It results from an interspecific cross between wheat and maize by double-hapolid method. 'BRS 331' shows solid stem in the base of the plant, short leaves and super-early cycle to maturity. It is classified as bread wheat in all of the regions that is recommended in the States of Rio Grande do Sul, Paraná and Santa Catarina, Brazil.
\end{abstract}

Key words: Triticum aestivum, crop breeding.

\section{INTRODUCTION}

Wheat (Triticum aestivum L.) is an autogamous species of worldwide adaptation and highly relevant for the Brazilian agriculture. Currently, Brazil consumes around 11 million tons of wheat per year, higher than the national cereal production, which reached 5.3 million tons in 2014 (CONAB 2015).

The purpose of the breeding program of Embrapa Wheat is to provide producers with cultivars that are competitive at the agronomic level and have an industrial quality appropriate for the different segments of the milling industry. Since 1974, more than 70 new cultivars were released for cultivation (Só e Silva et al. 2010, Caierão et al. 2014, Scheeren et al. 2014). Cultivar BRS 331 was developed in the framework of a partnership between Embrapa Wheat and the Fundação Pró-Sementes de Apoio à Pesquisa (Pro-Seed Research Support Foundation), which supervised the testing, marketing and distribution.

The objective of this study was to describe the yield performance, main agronomic traits and end-use profile of industrial suitability of the Embrapa Wheat cultivar BRS 331.

\section{BREEDING METHOD}

'BRS 331' was derived from the cross F68675 made in the winter of 2000, in a greenhouse of Embrapa Wheat, in Passo Fundo, RS. The parent lines were PF 990602, originated from a genotype developed in Pelotas, by Embrapa Clima Temperado, and WT 98109, a line developed by Embrapa Soja, in Londrina, PR.
Crop Breeding and Applied Biotechnology 17: 63-66, 2017 Brazilian Society of Plant Breeding. Printed in Brazil http://dx.doi.org/10.1590/198470332017v17n1c10 \title{
政
}


In 2001, the $F_{1}$ generation was grown in a greenhouse, in Passo Fundo, RS. In 2002, it was included in a plant collection called DHM (Double-Haploid line of maize) highlights. One ear was emasculated and pollination performed with maize pollen. In the laboratory, the resulting embryo was transferred to an appropriate growth medium, where a seedling was grown that originated $F 1_{D H}(\mathrm{DH} 16914)$. Three spikes of the $F_{1}$ generation were sown in the winter of 2003, of which one gave rise to PF 015733-C with characteristics of medium-sized with early cycle. In the winter of 2004, PF 015733-C was sown on an experimental field of Embrapa Wheat and included in the collection of new double-haploid wheat lines. In each generation, after threshing of the selected plots, the seeds were visually selected, and PF 015733-C had a superior performance in terms of grain filling. It was selected as outstanding and separated for testing.

\section{PERFORMANCE CHARACTERISTICS}

In 2005, line PF 015733-C was evaluated in the $18^{\text {th }}$ preliminary test set of Embrapa Wheat lines. In view of the continuously superior performance in the Preliminary Test Network (EPR) in 2006, the line was advanced for testing for the Cultivation and Use Value (VCU) in 2007. The VCU was determined in the tests of 2007, 2008 and 2010. All trials were arranged in a randomized block design with three replications. Each experimental unit, consisting of one genotype, was sown in five 5-m-long rows, spaced $0.2 \mathrm{~m}$ apart, with a total evaluated area of $5 \mathrm{~m}^{2}$. All cultural practices were applied according to the technical instructions of the commission for wheat and triticale research in Brazil (Comissão Brasileira de Pesquisa de Trigo e Triticale 2006, 2008 and 2009). Prior to sowing, the seeds of the tests were treated with triadimenol + imidacloprid. The trials were carried out in the states of Rio Grande do Sul, Santa Catarina and southern Paraná, in the regions of wheat adaptation 1 and 2 in different sites and sowing dates.

In 2007, 2008 and 2010, cultivar BRS 331 was compared with the controls BRS 208 and BRS Guamirim (in terms of relative percentage for the variable grain yield). The relative percentage of the consolidated performance of 'BRS 331' for the variable grain yield was $98 \%$ (2007), $97 \%$ (2008) and 103\% (2010) of the mean of the two controls each year. In the period of participation in the VCU tests, the relative percentage of the consolidated performance was $100 \%$ (Table 1). The highest mean grain yield of the cultivar was $4,950 \mathrm{~kg} \mathrm{ha}^{-1}$ in 2010 , while the general mean was $4,181 \mathrm{~kg} \mathrm{ha}^{-1}$.

'BRS 331' is a medium-sized cultivar with a super-short cycle (on average 125 days from emergence to maturity in Passo Fundo), moderately resistant to lodging and frost in the vegetative stage; susceptible to shattering and moderately resistant to pre-harvest sprouting; and susceptible to blight (Table 2). In relation to the main biotic stresses, it is resistant to Wheat Mosaic Virus (WMV), moderately resistant to powdery mildew (Blumeria graminis), spot blotch (Bipolaris sorokiniana) and scab (Fusarium graminearum). The reaction to tan spot and BYDV (barley yellow dwarf virus) was characterized as moderately susceptible. To leaf rust (Puccinia triticina), the reaction was classified as susceptible to the races B48, B53, B55, B57, and B59 in the seedling stage, in tests under controlled environmental conditions (growth chamber). The "field reaction" of the cultivar to leaf rust was classified as moderately susceptible.

Preliminarily, 'BRS 331' (line PF 015733-C) was classified as bread wheat ( $\mathrm{W} \geq 220 \times 10^{-4} \mathrm{~J}$ or stability $\geq 10 \mathrm{~min}$; falling number $\geq 220$ s), based on Instruction No. 38 of 30/11/2010 (Table 3). For the samples analyzed between 2006 and 2010, the Grain Quality Laboratory of Embrapa Wheat determined a mean gluten strength (W) of $223 \times 10^{-4} \mathrm{~J}$ and Elasticity Index (EI) of $50.1 \%$ in 37 samples from VCU test locations. For the Adaptation Region (AR) 1 the mean W value was $222 \times 10^{-4} \mathrm{~J}$

Table 1. Grain yield means ( $\mathrm{kg} \mathrm{ha}^{-1}$ ) of BRS 331 and the controls BRS 208 and BRS Guamirim, in 2007, 2008 and 2010

\begin{tabular}{|c|c|c|c|c|c|c|c|c|}
\hline \multirow{2}{*}{ Genotype } & \multicolumn{2}{|c|}{2007} & \multicolumn{2}{|c|}{2008} & \multicolumn{2}{|c|}{2010} & \multicolumn{2}{|c|}{ Mean } \\
\hline & $\left(\mathrm{kg} \mathrm{ha}^{-1}\right)$ & $\left(\%^{1}\right)$ & $\left(\mathrm{kg} \mathrm{ha}^{-1}\right)$ & $\left(\%^{1}\right)$ & $\left(\mathrm{kg} \mathrm{ha}^{-1}\right)$ & $\left(\%^{1}\right)$ & $\left(\mathrm{kg} \mathrm{ha}^{-1}\right)$ & $\left(\%^{1}\right)$ \\
\hline Locations & \multicolumn{2}{|c|}{8} & \multicolumn{2}{|c|}{9} & \multicolumn{2}{|c|}{10} & \multicolumn{2}{|c|}{27} \\
\hline BRS 331 & 3.286 & 98 & 4.306 & 97 & 4.950 & 103 & 4.181 & 100 \\
\hline BRS Guamirim & 3.443 & 103 & 4.654 & 105 & 4.640 & 97 & 4.246 & 102 \\
\hline BRS 208 & 3.262 & 97 & 4.229 & 95 & 4.963 & 103 & 4.151 & 98 \\
\hline $\mathrm{TM}^{2}$ & 3.352 & 100 & 4.442 & 100 & 4.801 & 100 & 4.198 & 100 \\
\hline
\end{tabular}

$1 \%$ mean percentage of the two best controls.

${ }^{2} \mathrm{TM}=$ Mean of controls BRS Guamirim and BRS 208.

Locations of evaluation in 2007: Passo Fundo/RS (2 sowing times), São Borja/RS, Três de Maio/RS, Vacaria/RS, Chapecó/SC, Campos Novos/SC and Guarapuava/PR. Locations of evaluation in 2008: Passo Fundo/RS (2 sowing times), São Borja/RS (2 sowing times), Três de Maio/RS ( 2 sowing times), Vacaria/RS, Chapecó/SC and Campos Novos/SC. Locations of evaluation in 2009: Passo Fundo/RS (2 sowing times), São Borja/RS (2 sowing times), Três de Maio/RS (2 sowing times), Vacaria/RS, Victor Graeff/ RS, Abelardo Luz/SC and Canoinhas/SC. 
Table 2. Description of the main agronomic characteristics of wheat cultivar BRS 331 compared with the controls BRS Guamirim and BRS 208

\begin{tabular}{|c|c|c|c|}
\hline Agronomic traits & BRS 331 & BRS Guamirim & BRS 208 \\
\hline Plant height & Medium & Low & Medium/High \\
\hline Cycle to heading & Super-early & Super-early & Medium \\
\hline Cycle to maturity & Super-early & Super-early & Medium \\
\hline Reaction to pre-harvest sprouting & S & MS & $\mathrm{S}$ \\
\hline Reaction to lodging & $\mathrm{R}$ & MR & $\mathrm{S} / \mathrm{MS}$ \\
\hline Reaction to common bacterial blight & S & MR & $\mathrm{R}$ \\
\hline Reaction to tan spot & MS & $\mathrm{MR}$ & MS \\
\hline Reaction to leaf rust & $\mathrm{S}^{1}$ and $\mathrm{MS}^{2}$ & $\mathrm{MR} / \mathrm{MS}$ & $\mathrm{MR}$ \\
\hline Reaction to scab & MR & MR & MS \\
\hline Reaction to BYDV & MS & $S$ & $\mathrm{MR}$ \\
\hline Reaction to WMV & $\mathrm{R}$ & MS & $\mathrm{MR}$ \\
\hline
\end{tabular}

$\mathrm{R}=$ Resistant; $\mathrm{MR}=$ Moderately resistant; $\mathrm{MS}=$ Moderately susceptible; $\mathrm{S}=$ Susceptible

${ }_{1}^{1}$ Races B48, B53, B55, B57 and B59 (in seedling stage).

2 in adult plants.

Table 3. Industrial quality of BRS 331 in the wheat adaptation regions 1 and 2

\begin{tabular}{lccc}
\hline Characteristics & Mean of region $\mathbf{1}^{\mathbf{1}}$ & Mean of region $\mathbf{2}^{\mathbf{2}}$ & General Mean \\
\hline Samples & 20 & 17 & 37 \\
Mean W & 222 & 226 & 223 \\
Mean L* & 92 & 91.5 & 91.71 \\
Mean b* & 11.2 & 10.8 & 11.01 \\
Tenacity (P) & 89 & 93 & 91 \\
Extensibility (L) & 71 & 65 & 68 \\
Mean P/L & 1.3 & 1.5 & 1.4 \\
Mean El & 49.6 & 50.7 & 50.1 \\
\hline
\end{tabular}

Samples = number of samples of each region; $W=$ Gluten strength $\left(\times 10^{-4}\right.$ Joules); $L^{*}=$ luminosity or flour whiteness (Minolta) - " 0 " = black and “ 100 " = white; $b^{*}=$ color $\mathrm{b}$ (Minolta) - "+" = yellow and "- = blue; P = Tenacity or maximum resistance to extension; L= Extensibility (mm); P/L = Tenacity/extensibility ratio; EI = Elasticity index in percentage.

${ }^{1}$ Representative locations of Region 1 - Passo Fundo/RS, Vacaria/RS, Victor Graeff/RS, Campos Novos/SC, Canoinhas/SC and Guarapuava/PR. ${ }^{2}$ Representative locations of Region 2 - São Borja/RS, Três de Maio/RS, Chapecó/SC and Abelardo Luz/SC

in 20 samples from the states of Rio Grande do Sul, Santa Catarina and Paraná, preliminarily classified as bread wheat. For AR 2, the mean W was $226 \times 10^{-4} \mathrm{~J}$ in 17 samples from Rio Grande do Sul and Southern Santa Catarina, classified in the same way as for AR 1. The other relevant traits for the industrial quality profile of the cultivar are presented in Table 3.

Cultivar BRS 331 has red grain with good resistance to "mottled grains". The grains are extra hard (mean hardness of 91, in SKCS equipment). Classified as bread wheat, it is suggested that this wheat is used for baking in general, fresh pasta, for cookies such as "crackers", domestic use (homemade cakes, cookies and bread), and for blends.

This cultivar represents a significant advance in terms of earliness and plant architecture, mainly about stem thickness, the short and erect leaves and the ear size.

Wheat cultivar 'BRS 331' was suitable for cultivation in AR 1 and 2 of the States of Rio Grande do Sul and Santa Catarina, as well as in AR 1 of Paraná.

\section{BASE SEED PRODUCTION}

BRS 331 is registered and protected by the Ministry of Agriculture, Livestock and Supply (MAPA) under numbers 28233 and 20120129, respectively. Embrapa Wheat is responsible for the genetic seed of the cultivar, the Embrapa Produtos e Mercado (SPM) for the Basic seed and the founders of the Fundação de Apoio a Pesquisa Pró-Sementes for the certified seed, in partnership with Embrapa. 


\section{PL Scheeren et al.}

\section{REFERENCES}

Caierao E, Scheeren PL, Só e Silva M, Castro RL (2014) History of wheat cultivars released by Embrapa in forty years of research. Crop Breeding and Applied Biotechnology 14: 216-223.

Comissão Brasileira de Pesquisa de Trigo e Triticale (2006) Indicações técnicas para trigo e triticale - safra 2007. Embrapa Trigo, Passo Fundo, 114p.

Comissão Brasileira de Pesquisa de Trigo e Triticale (2008) Indicações técnicas para trigo e triticale - safra 2008. Embrapa Trigo, Londrina, $147 p$.

Comissão Brasileira de Pesquisa de Trigo e Triticale (2009) Indicações técnicas para trigo e triticale - safra 2010. Embrapa Trigo, Veranópolis, 170p.

CONAB (2015) Série histórica de área semeada de trigo. Available at <http://www.conab.gov.br/conabweb>. Accessed in April 2015.

Scheeren PL, Caetano VR, Caierão E, Só e Silva M, Nascimento Jr A, Eichelberger L, Miranda MZ and Brammer SP (2014) BRS 328 Double haploid bread wheat cultivar. Crop Breeding and Applied Biotechnology 14: 65-67.

Só e Silva M, Caierão E, Scheeren PL, Eichelberger, L, Nascimento Jr A and Miranda MZ (2010) BRS 327 - a new bread wheat cultivar. Crop Breeding and Applied Biotechnology 10: 370-373. 